Nur Ahmad Ricky Rudianto: Tarif Pajak

\title{
TARIF PAJAK, PROBABILITAS PEMERIKSAAN PAJAK DAN TINGKAT KEPATUHAN PAJAK: SEBUAH STUDI EKSPERIMEN
}

\author{
Nur Ahmad Ricky Rudianto \\ Universitas Airlangga Surabaya \\ Email:ahmad.ricky.01@gmail.com
}

\begin{abstract}
This study examines the tax rates and probability of tax examination on taxpayer compliance. Based on experimental $2 \times 2$ factorial design data between subjects, participants given low tax rates manipulations tend to be more compliant than participants given high tax rates manipulations, as well as the probability of tax examination, participants tend to be more compliant on high probability of tax examination manipulation than low probability of tax examination manipulation. Lastly, the interaction effect results do not show significant results. It was found that tax compliance can be achieved more effectively when low tax rates combined with high probability of tax examination. This study contributes to the tax compliance literature especially with the specific topic of tax rates and Probability of tax examination.
\end{abstract}

Keyword: tax compliance, tax rates, probability of tax examination

\section{ABSTRAK}

Penelitian ini menguji tarif pajak dan probabilitas pemeriksaan terhadap kepatuhan wajib pajak. Berdasarkan pada data eksperimen berdesain $2 \times 2$ faktorial antar subyek, partisipan yang diberikan manipulasi tarif pajak yang rendah cenderung untuk lebih patuh dibandingkan partisipan yang diberikan manipulasi tarif pajak yang tinggi, begitu pula dengan probabilitas pemeriksaan pajak, partisipan cenderung lebih patuh pada probabilitas pemeriksaan pajak tinggi dibandingkan probabilitas pemeriksaan pajak rendah. Terkahir, hasil interaksi tidak menunjukkan hasil yang signifikan.. Ditemukan bahwa kepatuhan pajak dapat dicapai dengan lebih efektif ketika tarif pajak rendah dikombinasikan dengan probabilitas pemeriksaan yang tinggi. Penelitian ini berkontribusi pada literatur kepatuhan pajak khususnya dengan topik tarif pajak dan probabilitas pemeriksaan pajak.

Kata Kunci: kepatuhan pajak, tarif pajak, probabilitas pemeriksaan pajak 
Ihtiyath Vol. 2 No. 1 September 2018

\section{PENDAHULUAN}

Permasalahan kepatuhan pajak merupakan suatu permasalahan sejak pertama kali perpajakan diberlakukan (Andreoni et al., 1998). Wajib pajak memilih untuk menghindari pajak daripada membayar pajak sesuai hukum yang berlaku. Pada tahun 2015, data wajib pajak yang terdaftar dalam sistem administrasi Direktorat Jenderal Pajak (DJP) mencapai 30.044.103 WP yang terdiri dari 2.472.632 WP Badan dan 27.571.471 WP Orang Pribadi (OP). Dari jumlah tersebut, yang wajib menyampaikan SPT pajak tahunan sebesar 18.159.840 WP yang terdiri dari 1.184.816 WP Badan dan 16.975.024 WP OP. Dari jumlah 18.159.840 WP Wajib SPT tersebut, hanya 10.972.529 WP yang menyampaikan SPT Tahunan atau 60,42\% dari jumlah total WP Wajib SPT. Jumlah WP yang menyampaikan SPT tersebut terdiri atas 681.331 WP Badan dan 10.291.198 WP OP. Artinya, tingkat kepatuhan WP Badan baru mencapai 58,00\%, WP OP 60,63\%. Jumlah WP Badan sebesar 681.331 tentu merupakan jumlah yang kecil jika dibandingkan dengan tiga juta lebih perusahaan yang ada dan beroperasi di Indonesia. Dan 10.291.198 WP OP tampak tidak berarti jika dibandingkan dengan jumlah total 93 juta lebih penduduk Indonesia yang bekerja dan menerima penghasilan (pajak.go.id, 2016).

Kepatuhan pajak yang rendah disebabkan oleh perilaku wajib pajak yang berusaha untuk memperoleh keuntungan sebesar-besarnya dalam usaha mereka. Menurut Allingham dan Sandmo (1972), wajib pajak akan memutuskan jumlah penghasilan yang dilaporkan dan menganggung risiko dari keputusannya tersebut (Alm et al., 1992; Feld \& Frey, 2007). Wajib pajak cenderung untuk melakukan underreporting income, yang artinya memperkecil jumlah penghasilan yang dilaporkan untuk meningkatkan fungsi utilitasnya. Wajib pajak cenderung untuk melakukan underreporting income disebabkan oleh tarif pajak dan pemeriksaaan pajak (Kaplanoglou \& Rapanos, 2015; Puspitasari et al., 2015).

Tarif pajak merupakan persentase yang digunakan untuk menghitung jumlah pajak terutang. Penentuan tarif pajak pada suatu negara tergantung pada kondisi perekonomian suatu negara dan kemampuan masyarakat dalam membayar pajak. Dengan tarif pajak yang tinggi akan berdampak pada rendahnya kepatuhan pajak (Chau \& Leung, 2009). Torgler (2002) menyatakan dengan tarif pajak yang tinggi dapat menyebabkan wajib pajak akan melakukan underreporting income. Hal ini dilakukan karena persepsi wajib pajak terhadap tarif pajak tinggi dapat mengurangi keuntungan secara ekonomis (Puspitasari et al., 2015). Sehingga dapat dikatakan tarif pajak memberikan efek negatif terhadap kepatuhan pajak. 
Nur Ahmad Ricky Rudianto: Tarif Pajak

Untuk meningkatkan kepatuhan pajak diperlukan adanya pemeriksaan pajak. Dengan adanya pemeriksaan pajak, akan menimbulkan sikap kehati-hatian wajib pajak dalam melaporkan penghasilannya (Reinganum \& Wilde, 1985). Hal itu disebabkan adanya ketidakpastian dalam kemungkinan (probabilitas) dilakukannya pemeriksaan pajak (Asnawi et al., 2009). Probabilitas pemeriksaan pajak memberikan efek positif terhadap kepatuhan pajak, yang artinya probabilitas pemeriksaan yang tinggi dapat meningkatkan kepatuhan pajak (Alm \& McKee, 1998).

Penelitian mengenai kepatuhan pajak dilakukan menggunakan metode eksperimen dikarenakan keterbatasan data yang bisa menjadi objek penelitian (Puspitasari et al., 2015). Penelitian menggunakan metode eksperimen pertama kali digunakan oleh Allingham dan Sandmo (1972) untuk meneliti perilaku wajib pajak ketika menghadapi keputusan ketika menghadapi pengambilan keputusan melakukan underreporting income atau tidak. Selanjutnya dikembangkan oleh Yitzhaki (1974), Alm et al. (1992) dan Kaplanoglou dan Rapanos (2015) untuk mencari faktor-faktor yang mempengaruhi wajib pajak melakukan undereporting income yang menjadi masalah kepatuhan pajak. Sehingga perlu dilakukan penelitian lebih lanjut mengenai tarif pajak dan probabilitas pemeriksaan pajak yang berhubungan dengan kepatuhan pajak.

\section{KERANGKA TEORITIS DAN HIPOTESIS Expected Utility Theory}

Expected Utility Theory merupakan teori yang dikembangkan oleh Allingham dan Sandmo (1972) untuk mempelajari perilaku wajib pajak ketika menghadapi sebuah keputusan untuk melaporkan jumlah penghasilan ketika menghadapi pemeriksaan dan denda. Menurut Allingham dan Sandmo (1972), wajib pajak yang menerima pendapatan tetap akan melakukan underreported income, yaitu melaporkan penghasilannya lebih kecil dari yang sebenarnya untuk memaksimalkan fungsi utilitasnya dan menanggung akibat jika terdeteksi ketika dilakukan pemeriksaan. Underreporting Income merupakan masalah kepatuhan yang berhubungan dengan etika wajib pajak dalam melaporkan penghasilannya (Friedland et al., 1978).

Wajib pajak melakukan underreporting income disebabkan oleh beberapa hal, antara lain perlakuan fiskus, tarif pajak, etika, pemeriksaan pajak, atau denda (Andreoni et al., 1998). Tarif pajak merupakan salah satu hal yang mempengaruhi wajib pajak untuk melakukan 
Ihtiyath Vol. 2 No. 1 September 2018

underreporting income. Semakin tinggi tarif pajak akan semakin besar wajib pajak akan melakukan underreporting income. Pemeriksaan pajak dilakukan untuk mengatasi masalah kepatuhan tersebut. Dengan adanya pemeriksaan pajak, akan menimbulkan sikap kehati-hatian wajib pajak dalam melaporkan penghasilannya (Reinganum \& Wilde, 1985). Hal itu disebabkan adanya ketidakpastian dalam kemungkinan (probabilitas) dilakukannya pemeriksaan pajak (Asnawi et al., 2009). Probabilitas pemeriksaan pajak memberikan efek positif terhadap kepatuhan pajak, yang artinya probabilitas pemeriksaan yang tinggi dapat meningkatkan kepatuhan pajak (Alm \& McKee, 1998).

\section{Kepatuhan Pajak}

Menurut Feld dan Frey (2007), kepatuhan pajak merupakan implikasi dari adanya sebuah hubungan kontraktual antara kewajiban (duties) dan hak (rights) dari masing-masing pihak yang melakukan kontrak tersebut, yaitu Wajib Pajak (taxpayers) dan negara (state). Wajib Pajak (WP) akan melaporkan besarnya penghasilan yang diperoleh sesuai dengan ketentuan fiskal yang telah ditetapkan oleh pemerintah, dengan catatan akan menerima fasilitas publik yang sebanding dengan besarnya pajak yang telah dikeluarkan dalam proses legitimasi yang wajar. Kriteria Wajib Pajak patuh sesuai dengan Peraturan Menteri Keuangan nomor 74/PMK.03/2012 adalah Wajib Pajak yang memenuhi persyaratan sebagai berikut:

1. Tepat waktu dalam menyampaikan SPT

2. Tidak mempunyai tunggakan pajak untuk semua jenis pajak, kecuali tunggakan pajak yang telah memperoleh izin mengangsur atau menunda pembayaran pajak

3. Laporan keuangan diaudit oleh Akuntan Publik atau lembaga pengawasan keuangan pemerintah dengan pendapat Wajar Tanpa Pengecualian selama 3 (tiga) tahun berturut-turut

Tidak pernah dipidana karena melakukan tindak pidana di bidang perpajakan berdasarkan putusan pengadilan yang telah mempunyai kekuatan hukum tetap dalam jangan waktu 5 (lima) tahun terakhir.

Beberapa otoritas pajak, seperti IRS (2009), ATO (2009) dan IRB (2009) dalam (Palil, 2005) mendefinisikan kepatuhan pajak sebagai kemampuan atau kesanggupan dan kemauan wajib pajak untuk mematuhi peraturan pajak, mengungkapkan jumlah dan sum- 
ber penghasilan yang sesungguhnya setiap tahun, dan membayar pajak dalam jumlah yang benar dan tepat waktu. permasalahan mengenai kepatuhan pajak berkaitan dengan bagaimana memasukkan dan melaporkan semua informasi dengan tepat pada waktunya, mengisi secara benar jumlah pajak terhutang dan membayar pajak pada waktunya tanpa ada tindakan pemaksaan.

\section{Tarif Pajak}

Menurut Tjahjono (2005:21), tarif pajak merupakan angka atau persentase yang digunakan untuk menghitung jumlah pajak atau jumlah pahak terhutang. Tujuan dari pembentukan tarif pajak adalah untuk mencapai keadilan. Pemungutan pajak tidak terlepas dari keadilan, hanya keadilan yang dapat menciptakan keseimbangan sosial, yang sangat penting untuk kesejahteraan masyarakat umum dan dapat mencegah segala macam sengketa dan pertengkaran. Tarif harus didasarkan atas pemahaman setiap orang mempunyai hak yang sama, sehingga tercapai tarif-tarif pajak yang proporsional atau sebanding.

\section{Probabilitas Pemeriksaan Pajak}

Menurut Waluyo (2007) dalam Rahman (2011), pemeriksaan pajak merupakan kegiatan mengumpulkan dan mengolah data atau bukti lainnya dengan tujuan untuk menguji kepatuhan dalam memenuhi kewajiban perpajakan sesuai dengan peraturan perpajakan yang berlaku. Untuk meningkatkan kepatuhan pajak, probabilitas dilakukannya pemeriksaan pajak juga perlu ditingkatkan. penggelapan dan penghindaran pajak diharapkan dapat dihindari. Probabilitas pemeriksaan pajak memberikan efek positif terhadap kepatuhan pajak, yang artinya probabilitas pemeriksaan yang tinggi dapat meningkatkan kepatuhan pajak (Alm \& McKee, 1998). Dengan adanya probabilitas pemeriksaan pajak tinggi, akan menimbulkan sikap kehati-hatian wajib pajak dalam melaporkan penghasilannya (Reinganum \& Wilde, 1985). Hal itu disebabkan adanya ketidakpastian dalam kemungkinan dilakukannya pemeriksaan pajak (Asnawi et al., 2009).

\section{Kerangka Konseptual}

Penelitian ini didasari dari sebuah fenomena di indonesia dimana semakin banyak masyarakat indonesia yang kurang patuh pajak yang dapat menyebabkan berkurangnya penghasilan negara. Ada beberapa alasan mengapa masih banyak para wajib pajak yang 
Ihtiyath Vol. 2 No. 1 September 2018

tidak patuh terhadap pajak, salah satunya karena tingginya tarif pajak yang ditetapkan oleh negara. Karena hal tersebut para wajib pajak sering melakukan kecurangan dengan meminimalkan penghasilan bruto yang didapatkannya agar bisa menghindari pajak atau bisa memperkecil kewajiban pajaknya. Salah satu cara yang dilakukan negara untuk meningkatkan kepatuhan wajib pajak adalah melakukan pemeriksaan pajak.. Pemeriksaan pajak dilakukan dengan tujuan untuk menguji keapatuhan wajib pajak dalam memenuhi kewajiban perpajakan sesuai dengan undang-undang perpajakan. Pemeriksaan pajak dikatakan memberi efek positif terhadap kepatuhan perpajakan, yang artinya pemeriksa an pajak dapat meningkatkan kepatuhan wajib pajak dalam memenuhi kewajiban perpajakannya (Puspitasari et al., 2015; Rahman, 2011).

Berdasarkan penjelasan diatas maka dalam penelitian ini dijelaskan menngenai apakah adanya pemeriksaaan pajak dan tingginya tarif pajak dapat mempengaruhi kepatuhan wajib pajak, dasar pemikiran ini tersaji didalam kerangka konseptual berikut ini.

\section{Gambar 1}

\section{Kerangka Konseptual}

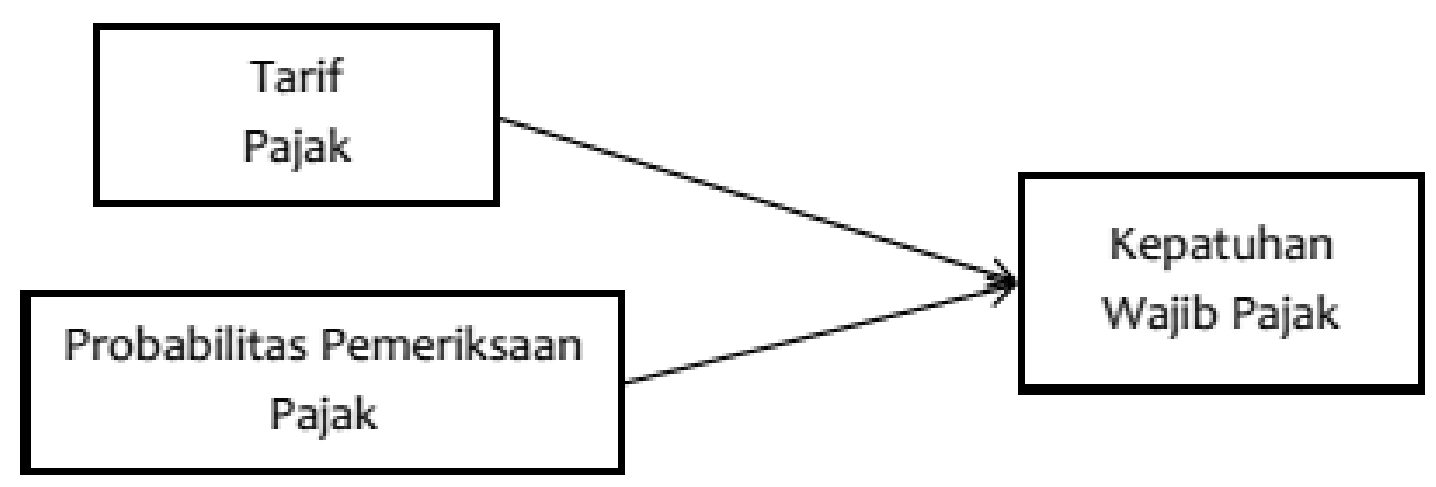

\section{Pengaruh Tarif Pajak Terhadap Tingkat Kepatuhan Wajib Pajak}

Tarif pajak merupakan bagian dari penghasilan yang harus dibayarkan kepada negara oleh wajib pajak. Dengan tarif pajak yang tinggi akan berdampak pada rendahnya kepatuhan pajak (Chau \& Leung, 2009). Torgler (2002) menyatakan dengan tarif pajak yang tinggi dapat menyebabkan wajib pajak akan melakukan underreporting income. Begitu juga sebaliknya, Dengan tarif pajak yang rendah akan meningkatkan kepatuhan pajak, karena 
Nur Ahmad Ricky Rudianto: Tarif Pajak

dengan rendahnya tarif pajak akan meningkatkan fungsi utilitas wajib pajak. Persepsi wajib pajak terhadap tarif pajak tinggi dapat mengurangi keuntungan secara ekonomis (Puspitasari et al., 2015). Sehingga dapat diambil kesimpulan bahwa tarif pajak berpengaruh negatif terhadap kepatuhan wajib pajak.

$\mathrm{H}_{1} \quad$ : Wajib Pajak dengan kondisi tarif pajak yang rendah cenderung lebih patuh dibandingkan wajib pajak yang berada pada kondisi tarif pajak tinggi.

\section{Pengaruh Probabilitas Pemeriksaan Pajak Terhadap Tingkat Kepatuhan Wajib Pajak}

Pemeriksaan pajak dilakukan dengan tujuan untuk meningkatkan kepatuhan pajak. Dengan adanya pemeriksaan pajak, akan menimbulkan sikap kehati-hatian wajib pajak dalam melaporkan penghasilannya (Reinganum \& Wilde, 1985). Hal itu disebabkan adanya ketidakpastian dalam kemungkinan (probabilitas) dilakukannya pemeriksaan pajak (Asnawi et al., 2009). Probabilitas pemeriksaan pajak memberikan efek positif terhadap kepatuhan pajak, yang artinya probabilitas pemeriksaan yang tinggi dapat meningkatkan kepatuhan pajak (Allingham \& Sandmo, 1972; Alm \& McKee, 1998)

$\mathrm{H}_{2} \quad$ : Wajib Pajak dengan kondisi probabilitas pemeriksaan pajak yang tinggi cenderung lebih patuh dibandingkan individu dalam kondisi probabilitas pemeriksaan pajak rendah.

\section{Pengaruh Interaksi Antara Tarif Pajak dan Probabilitas Pemeriksaan Pajak Terhadap Tingkat Kepatuhan Wajib Pajak}

Menurut Alm et al. (1992), tarif pajak memberikan efek negatif terhadap kepatuhan pajak. Sebaliknya, pemeriksaan pajak memberikan pengaruh positif terhadap kepatuhan pajak (Alm \& McKee, 1998). Individu dengan kondisi tarif pajak rendah akan meningkatkan kepatuhan pajak (Chau \& Leung, 2009). Begitu juga dengan kondisi probabilitas pemeriksaan pajak yang tinggi (Spicer \& Thomas, 1982). Sehingga individu dengan kondisi tarif pajak rendah dan probabilitas pajak yang tinggi memiliki tingkat kepatuhan yang paling tinggi dibandingkan dengan kondisi tarif dan probabilitas pemeriksaan pajak yang lain. 
Ihtiyath Vol. 2 No. 1 September 2018

$\mathrm{H}_{\text {за }} \quad$ : Interaksi antara kondisi tarif pajak rendah dan probabilitas pemeriksaan pajak tinggi memiliki tingkat kepatuhan yang paling tinggi.

Individu dengan kondisi tarif pajak tinggi akan mengurangi kepatuhan pajak (Alm et al., 1992). Begitu juga dengan kondisi probabilitas pemeriksaan pajak yang rendah (Allingham \& Sandmo, 1972). Sehingga individu dengan kondisi tarif pajak tinggi dan probabilitas pajak yang rendah memiliki tingkat kepatuhan yang paling rendah dibandingkan dengan kondisi tarif dan probabilitas pemeriksaan pajak yang lain.

$\mathrm{H}_{3 b} \quad$ : Interaksi antara kondisi tarif pajak tinggi dan probabilitas pemeriksaan pajak rendah memiliki tingkat kepatuhan yang paling rendah

\section{METODE PENELITIAN} Jenis Penelitian

Penelitian yang dilakukan menggunakan metode eksperimen. Metode eksperimen merupakan metode yang dilakukan untuk meneliti suatu fenomena dengan cara memanipulasi suatu keadaan sesuai prosedur yang diberikan peneliti (Nahartyo, 2012:1). Penelitian ini menggunakan desain between-subject $2 \times 2$ yang artinya terdapat dua level kondisi pemeriksaan pajak dan dua level kondisi tarif pajak

Tabel 1

Desain Penelitian

\begin{tabular}{|c|c|c|c|}
\hline \multirow{2}{*}{\multicolumn{2}{|c|}{ Tinggi }} & \multicolumn{2}{|c|}{ Tarif Pajak } \\
\hline & & Rendah & \\
\hline \multirow{2}{*}{$\begin{array}{c}\text { Probabilitas } \\
\text { Pemeriksaan } \\
\text { Pajak }\end{array}$} & Tinggi & Grup 1 & Grup 2 \\
\hline & Rendah & Grup 3 & Grup 4 \\
\hline
\end{tabular}

Peneliti membedakan partisipan menjadi empat grup:

Grup 1 : Kelompok dengan kondisi tarif pajak tinggi dan probabilitas pemeriksaan pajak tinggi

Grup 2 : Kelompok dengan kondisi tarif pajak rendah dan probabilitas pemeriksaan pajak tinggi

Grup 3: Kelompok dengan kondisi tarif pajak rendah dan probabilitas pemeriksaan pajak rendah

Grup 4: Kelompok dengan kondisi tarif pajak rendah dan probabilitas pemeriksaan pajak 
rendah

\section{Definisi Operasional dan Pengukuran Variabel Variabel Dependen}

Kepatuhan wajib pajak merupakan sikap wajib pajak melaporkan dan membayar pajak sesuai dengan peraturan pajak yang berlaku. Kepatuhan wajib pajak diukur menggunakan skala 1-10. Semakin tinggi penilaian yang diberikan partisipan, semakin tinggi tingkat kepatuhan partisipan dalam melaporkan dan membayar pajak.

\section{Variabel Independen \\ Tarif Pajak}

Pada variabel tarif pajak, terdapat dua level tarif yaitu tarif pajak tinggi dan tarif pajak rendah. Kondisi tarif pajak tinggi akan diberikan pada grup 1 dan grup 3. Kondisi tarif pajak rendah akan diberikan pada grup 2 dan grup 4 . Variabel tarif pajak diberikan kepada partisipan dengan cara memberikan suatu informasi tertulis mengenai tarif pajak yang dibebankan sesuai dengan peredaran bruto tertentu. Partisipan yang berada di grup 1 dan 3 menerima kondisi tarif pajak tinggi

\section{Probabilitas Pemeriksaan Pajak}

Pada variabel probabilitas pemeriksaan pajak, terdapat dua level probabilitas yaitu probabilitas pemeriksaan pajak tinggi dan probabilitas pemeriksaan pajak rendah. Kondisi probabilitas pemeriksaan pajak tinggi akan diberikan kepada grup 1 dan grup 2. Kondisi probabilitas pemeriksaan pajak rendah akan diberikan kepada grup 3 dan grup 4. Probabilitas yang digunakan adalah berupa persentase terjadinya pemeriksaan pajak.

\section{Jenis dan Sumber Data}

Jenis data dalam penelitian ini merupakan data kuantitatif. Sumber data adalah data primer, data yang diperoleh langsung dari sumbernya.

\section{Partisipan Penelitian}

Penelitian ini menggunakan eksperimen laboratorium dengan partisipan adalah mahasiswa S-1 Akuntansi Fakultas Ekonomi dan Bisnis Universitas Airlangga. Menurut Nahartyo 
Ihtiyath Vol. 2 No. 1 September 2018

(2012), mahasiswa dipilih sebagai partisipan karena perilaku dalam subjek mahasiswa dianggap tidak berbeda dengan subjek yang berasal dari latar belakang yang berbeda. Hal ini disebabkan penelitian lebih ditekankan pada aspek bagaimana partisipan memproses informasi dan mengambil keputusan secara umum.

\section{Protokol Eksperimen}

\section{Gambar 2}

Alur Eksperimen

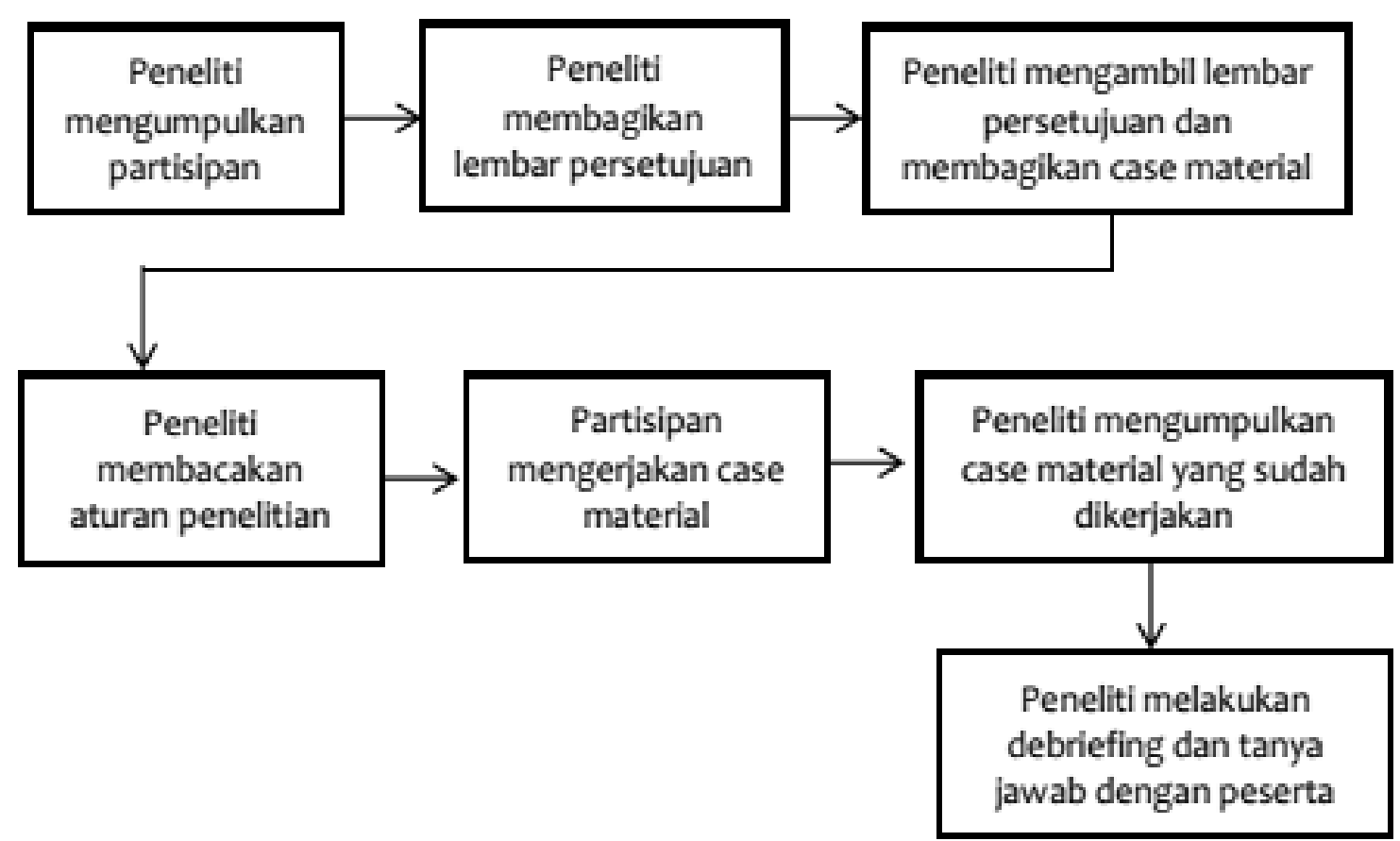

\section{Teknik Analisis Data}

Pengujian hipotesis dalam penelitian ini menggunakan Analyisis of Variance (ANOVA). ANOVA merupakan metode untuk menguji perbedaan rerata antar grup. Sebelum melakukan pengujian menggunakan ANOVA, peneliti menganalisis data demografi partisipan menggunakan statistik deskriptif. Dalam pengujian ANOVA, tingkat signifikansi yang digunakan adalah 5\% dan 10\% (Hair et al., 2010). $\mathrm{H}_{\alpha}$ diterima jika nilai signifikansi dibawah 5\% atau 10\%. Aplikasi statistik yang digunakan adalah SPSS Statistics 20. 


\section{HASIL DAN PEMBAHASAN}

\section{Data Penelitian}

Penelitian dilakukan pada tanggal 22 dan 27 November 2017 yang melibatkan 117 mahasiswa S-1 Akuntansi Universitas Airlangga sebagai subjek penelitian. Data hasil penelitian dari 117 mahasiswa ditunjukkan pada tabel 2.

Tabel 2

Hasil Penelitian

\begin{tabular}{|c|c|c|c|c|c|}
\hline \multirow{2}{*}{ Data } & \multicolumn{4}{|c|}{ Grup } & \multirow{2}{*}{ Jumlah (\%) } \\
\cline { 2 - 5 } Total & $\mathbf{1}$ & $\mathbf{2}$ & $\mathbf{3}$ & $\mathbf{4}$ & \\
\hline $\begin{array}{c}\text { Tidak Lolos Cek Manipulasi } \\
\text { (tidak dianalisis) }\end{array}$ & 30 & 29 & 29 & 29 & $117(100 \%)$ \\
\hline Lolos Cek Manipulasi (dianalisis) & 24 & 22 & 24 & 23 & $93(79,49 \%)$ \\
\hline
\end{tabular}

Pada tabel 1, dapat dilihat bahwa 6 data penelitian dari grup 1, 7 partisipan dari grup 2, 5 data penelitian dari grup 3, dan 6 data penelitian dari grup 4 tidak lolos cek manipulasi. Sehingga $24(20,51 \%)$ data hasil penelitian tidak dianalisis lebih lanjut. Data hasil penelitian yang akan dianalisis lebih lanjut sebanyak 93 (79,49\%) data penelitian.

\section{Uji Randomisasi}

Uji randomisasi dilakukan untuk memastikan tidak ada karakteristik dari subjek penelitian yang mempengaruhi kepatuhan pajak. Karakteristik yang diuji adalah jenis kelamin, usia, dan pengalaman kerja subjek penelitian. Hasil uji randomisasi jenis kelamin, usia, dan pengalaman kerja terhadap kepatuhan pajak ditunjukkan pada tabel 3

Tabel 3

Hasil Uji Randomisasi

\begin{tabular}{|l|l|l|l|}
\hline Variabel & Df & F $_{\text {hitung }}$ & Sig \\
\hline Jenis Kelamin & 6 & 10,415 & 0,108 \\
\hline Usia & 6 & 2,916 & 0,819 \\
\hline Pengalaman Kerja & 6 & 5,691 & 0,459 \\
\hline
\end{tabular}

Berdasarkan tabel 3, Hasil uji randomisasi jenis kelamin menunjukkan nilai signifikansi 0,108 yang lebih besar dari taraf signifikansi $5 \%(0,108>0,05)$. Hasil tersebut menyimpul- 
Ihtiyath Vol. 2 No. 1 September 2018

kan bahwa jenis kelamin partisipan tidak mempengaruhi kepatuhan pajak.

Hasil uji randomisasi usia menunjukkan nilai signifikansi 0,819 yang lebih besar dari taraf signifikansi 5\% (0,819>0,05). Hasil tersebut menyimpulkan bahwa usia partisipan tidak mempengaruhi kepatuhan pajak. Hasil uji randomisasi pengalaman kerja menunjukkan nilai signifikansi 0,459 yang lebih besar dari taraf signifikansi 5\% (0,459>0,05). Hasil tersebut menyimpulkan bahwa pengalaman kerja partisipan tidak mempengaruhi kepatuhan pajak. Dari hasil uji randomisasi di atas, dapat disimpulkan bahwa teknik randomisasi secara efektif dilakukan pada penelitian ini. Yang artinya setiap subjek penelitian mendapatkan satu kasus tanpa memperhatikan karakteristik dari subjek tersebut.

\section{Uji Hipotesis}

Data hasil eksperimen ditunjukkan pada tabel 4 dengan menampilkan jumlah subjek, rata-rata, dan standar deviasi setiap grup.

Tabel 4

Data Subjek Eksperimen Per Grup

\begin{tabular}{|c|c|c|c|c|}
\cline { 3 - 4 } \multicolumn{2}{c|}{} & \multicolumn{2}{c|}{ Tarif Pajak } & \multirow{2}{*}{ Total } \\
\cline { 3 - 4 } \multicolumn{1}{c|}{ Tinggi } & Rendah & \\
\hline \multirow{4}{*}{$\begin{array}{c}\text { Probabilitas } \\
\text { Pemeriksaan } \\
\text { Pajak }\end{array}$} & Tinggi & $\begin{array}{c}\text { Grup 1 } \\
(\mathrm{N}=24) \\
\text { Mean=8,792 } \\
\text { Std=1,179 }\end{array}$ & $\begin{array}{c}\text { Grup 2 } \\
(\mathrm{N}=22) \\
\text { Mean=8,955 } \\
\text { Std=1,290 }\end{array}$ & $\begin{array}{c}\text { Mean=8,87 } \\
\text { Std=1,222 }\end{array}$ \\
\cline { 3 - 5 } & Rendah & $\begin{array}{c}\text { Grup 3 } \\
(\mathrm{N}=24) \\
\text { Mean=7,75 } \\
\text { Std=1,8 }\end{array}$ & $\begin{array}{c}\text { Grup 4 } \\
(\mathrm{N}=23)\end{array}$ & $\begin{array}{c}\text { Mean=8,170 } \\
\text { Std=1,672 }\end{array}$ \\
\hline & Total & $\begin{array}{c}(\mathrm{N}=48) \\
\text { Mean=8,271 } \\
\text { Std=1,594 }\end{array}$ & $\begin{array}{c}\text { Mean=8,778 } \\
\text { Std=1,363 }\end{array}$ & $\begin{array}{c}\text { Mean=8,516 } \\
\text { Std=1,501 }\end{array}$ \\
\hline
\end{tabular}

Pengujian hipotesis dilakukan dengan menggunakan ANOVA untuk menguji adanya pengaruh antara tarif pajak dan probabilitas pemeriksaan pajak terhadap kepatuhan wajib pajak. Hasil uji hipotesis dapat dilihat pada tabel 5 . 
Nur Ahmad Ricky Rudianto: Tarif Pajak

Tabel 5

Hasil Uji Hipotesis

\begin{tabular}{|c|c|c|c|c|}
\hline Variabel Independen & Df & $\mathbf{F}_{\text {hitung }}$ & Sig & Keterangan \\
\hline Tarif & 1 & 2,885 & 0,093 & $\mathrm{H}_{1}$ tidak ditolak \\
\hline Probabilitas Pemeriksaan & 1 & 5,322 & 0,023 & $\mathrm{H}_{2}$ tidak ditolak \\
\hline Tarif*Pemeriksaan & 1 & 1,338 & 0,250 & $\mathrm{H}_{3}$ ditolak \\
\hline
\end{tabular}

Variabel Dependen: Kepatuhan Pajak

Hasil uji untuk hipotesis 1 (tabel 5) menunjukkan signifikan pada 10\% $(0,093<0,1)$ dan rata-rata pada tarif pajak rendah menunjukkan hasil 8,778 (tabel 4) jika dibandingkan dengan rata-rata pada tarif pajak tinggi yang menunjukkan hasil 8,271. Dapat disimpulkan bahwa Wajib Pajak dengan kondisi tarif pajak yang rendah cenderung lebih patuh dibandingkan wajib pajak yang berada pada kondisi tarif pajak tinggi.

Hasil uji untuk hipotesis 2 (tabel 5) menunjukkan signifikan pada $5 \%(0,023<0,1)$ dan rata-rata pada probabilitas pemeriksaan tinggi menunjukkan hasil 8,87 (tabel 4) jika dibandingkan dengan rata-rata pada probabilitas pemeriksaan rendah yang menunjukkan hasil 8,170. Dapat disimpulkan bahwa Wajib Pajak dengan kondisi probabilitas pemeriksaan pajak yang tinggi cenderung lebih patuh dibandingkan wajib pajak yang berada pada kondisi probabilitas pemeriksaan pajak rendah.

Hipotesis 3 menunjukkan adanya interaksi antara tarif dan probabilitas pemeriksaan pajak terhadap kepatuhan pajak. Hipotesis za menyatakan Interaksi antara kondisi tarif pajak rendah dan probabilitas pemeriksaan pajak tinggi memiliki tingkat kepatuhan yang paling tinggi. Hipotesis zb menyatakan bahwa Interaksi kondisi tarif pajak tinggi dan probabilitas pemeriksaan pajak rendah memiliki tingkat kepatuhan yang paling rendah. Rata -rata pada grup 2 yang memiliki kondisi tarif pajak rendah dan probabilitas pemeriksaan tinggi menunjukkan hasil 8,955 (tabel 4) yang menunjukkan Wajib pajak pada grup 2 memiliki nilai kepatuhan paling tinggi dibandingkan grup lainnya. Rata -rata pada grup 3 yang memiliki kondisi tarif pajak tinggi dan probabilitas pemeriksaan rendah menunjukkan hasil 7,75 (tabel 4) yang menunjukkan Wajib pajak pada grup 3 memiliki nilai kepatuhan paling rendah dibandingkan grup lainnya. Akan tetapi, hasil uji untuk hipotesis 3 (tabel 5) menunjukkan tidak signifikan pada 10\% (0,250 > 0,1). Hal ini menunjukkan bahwa tidak ada interaksi antara tarif pajak dan probabilitas pemeriksaan pajak. 
Ihtiyath Vol. 2 No. 1 September 2018

\section{Pembahasan}

Hipotesis 1 menyatakan bahwa semakin rendah tarif pajak maka wajib pajak akan semakin patuh. Hal tersebut dapat dilihat pada gambar 3.

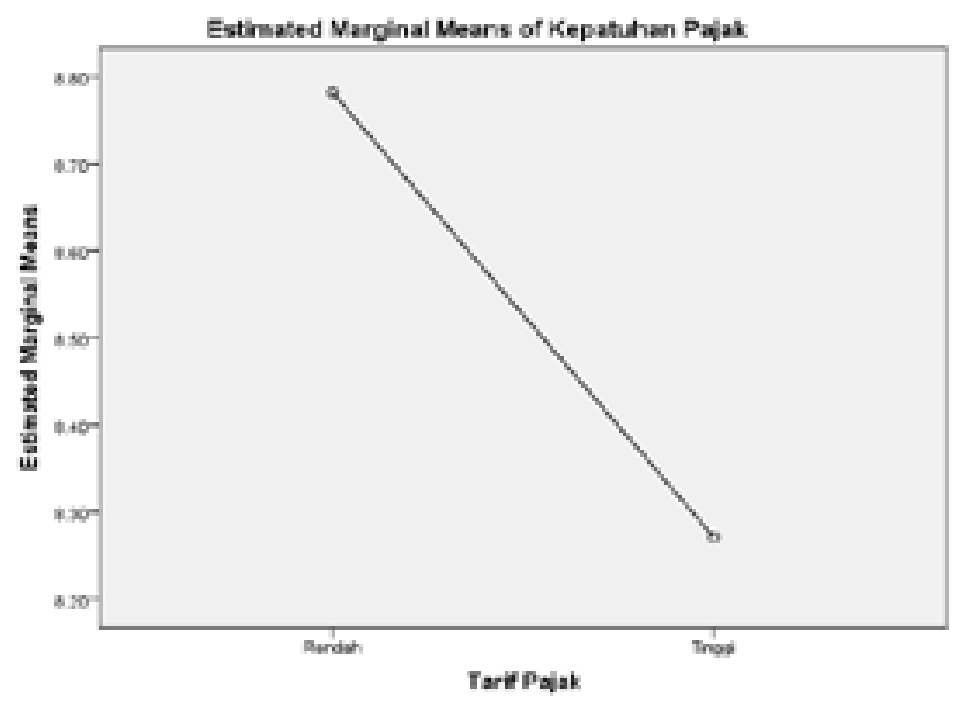

Gambar 3. Grafik Tarif Pajak Terhadap Kepatuhan Pajak

Hasil dari penelitian ini mendukung pendapat (Chau \& Leung, 2009) yang menyatakan jika tarif pajak tinggi maka kepatuhan pajak akan semakin rendah. Torgler (2002) menyatakan dengan tarif pajak yang tinggi dapat menyebabkan wajib pajak akan melakukan underreporting income. Hal ini dilakukan karena persepsi wajib pajak terhadap tarif pajak tinggi dapat mengurangi keuntungan secara ekonomis (Puspitasari et al., 2015). Sehingga dapat dikatakan tarif pajak memberikan efek negatif terhadap kepatuhan pajak.

Dengan hasil tersebut maka penelitian ini mendukung teori expected utility, dimana mengasumsikan bahwa wajib pajak akan melakukan underreporting income ketika akan membayar pajak untuk memaksimalkan fungsi utilitasnya (Allingham \& Sandmo, 1972). wajib pajak melakukan underreporting income dengan tujuan pajak yang harus dibayar semakin kecil sehingga meningkatkan fungsi utilitasnya.

Hipotesis 2 menyatakan bahwa semakin tinggi probabilitas pemeriksaan maka wajib pajak akan semakin patuh. Hal tersebut dapat dilihat pada gambar 4. 


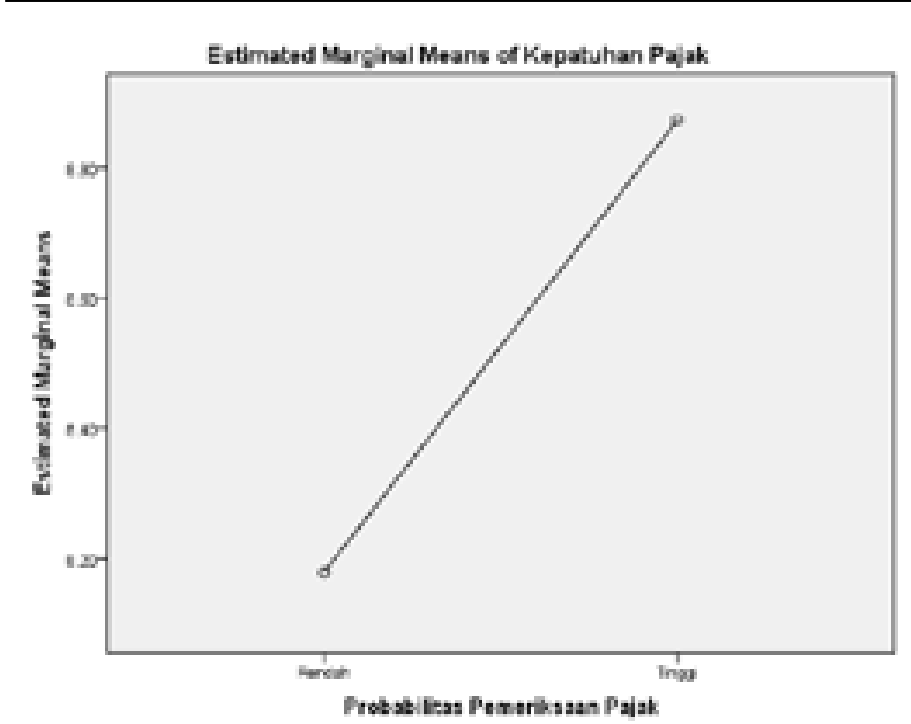

\section{Gambar 4. Grafik Probabilitas Pemeriksaan Terhadap Kepatuhan Pajak}

Hasil dari penelitian menunjukkan probabilitas pemeriksaan pajak dapat meningkatkan kepatuhan wajib pajak (Alm \& McKee, 1998). Adanya probabilitas pemeriksaan mempengaruhi wajib pajak untuk tidak melakukan underreporting income. Wajib pajak cenderung untuk melaporkan pajaknya sesuai pendapatan yang dimiliki. Pemeriksaan pajak menimbulkan sikap kehati-hatian wajib pajak dalam melaporkan penghasilannya (Reinganum \& Wilde, 1985). Hal tersebut disebabkan adanya ketidakpastian dalam kemungkinan dilakukan pemeriksaan pajak (Asnawi et al., 2009).

Hasil penelitian untuk hipotesis 3 tidak menunjukkan adanya interaksi antara tarif pajak dan probabilitas pemeriksaan pajak terhadap kepatuhan pajak. Hal tersebut dapat dilihat pada gambar 5 .

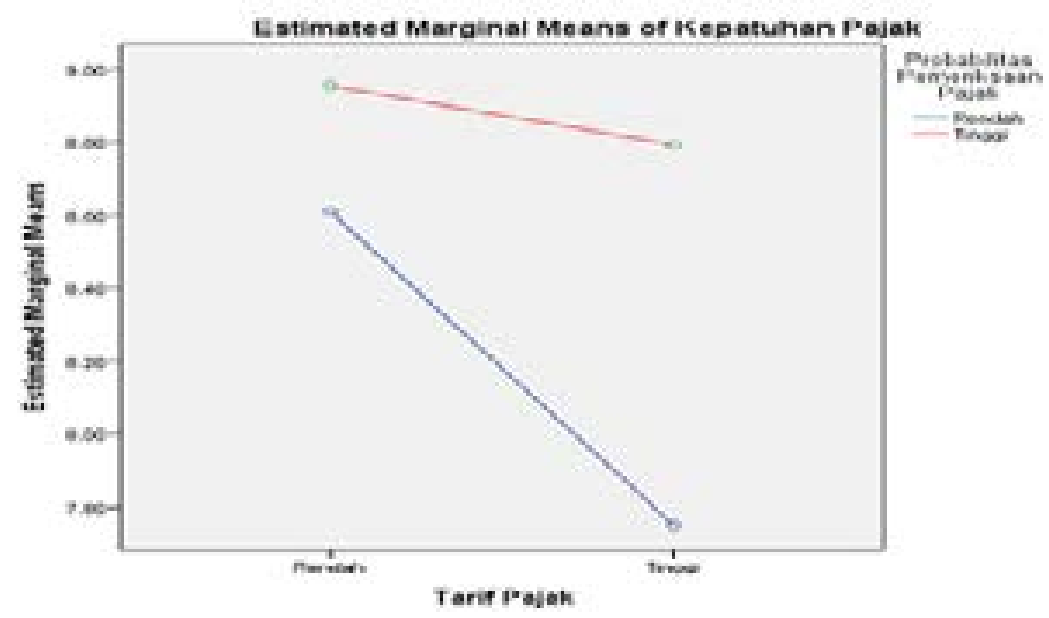


Ihtiyath Vol. 2 No. 1 September 2018

\section{Gambar 5. Grafik Interaksi antara Tarif Pajak dan Probabilitas Pemeriksaan Pajak}

Dapat dilihat dari gambar 5, Wajib pajak dengan kondisi tarif pajak tinggi tetap melakukan underreporting income meskipun terdapat probabilitas pemeriksaan pajak. Dengan adanya peningkatan tarif pajak, akan mengurangi penghasilan wajib pajak secara ekonomi, sehingga wajib pajak melakukan underreporting income untuk meningkatkan fungsi utilitasnya dan menanggung akibat jika terdapat pemeriksaan pajak (Allingham \& Sandmo, 1972).

\section{SIMPULAN DAN SARAN}

Beberapa simpulan yang dapat dirumuskan adalah sebagai berikut:

1. Tarif pajak mempengaruhi berkurangnya kepatuhan wajib pajak, yang mana tarif pajak yang tinggi dapat mengurangi kepatuhan wajib pajak dibandingkan dengan tarif pajak rendah. Tarif pajak yang tinggi cenderung untuk memotivasi wajib pajak untuk melakukan underreporting income.

2. Probabilitas pemeriksaan pajak meningkatkan kepatuhan wajib pajak. probabilitas pemeriksaan pajak yang tinggi dapat meningkatkan kepatuhan wajib pajak dibandingkan probabilitas pemeriksaan pajak rendah. Probabilitas pemeriksaan pajak tinggi dapat mengurangi motivasi wajib pajak untuk melakukan underreporting income.

3. Hubungan antara tarif pajak dan kepatuhan pajak tidak dipengaruhi adanya probabilitas pemeriksaan pajak. Wajib pajak tetap melakukan underreporting income pada kondisi tarif pajak tinggi meskipun terdapat probabilitas pemeriksaan pajak.

Saran peneilitian ini adalah

1. Untuk memperoleh validitas eksternal yang lebih baik, penelitian selanjutnya dapat melakukan survey di lapangan agar kasus yang yang diberikan lebih sesuai dengan realita di lapangan.

2. Pemilihan partisipan eksperimen lebih baik dilakukan secara hati-hati dengan memperhatikan kelas (malam atau siang) yang diikuti oleh partisipan untuk mengurangi bias eksperimen.

\section{DAFTAR PUSTAKA}

Allingham, M. G., \& Sandmo, A. (1972). Income tax evasion: A theoretical analysis. Journal of public economics, 1(3-4), 323-338. 
Nur Ahmad Ricky Rudianto: Tarif Pajak

Alm, J., Jackson, B. R., \& McKee, M. (1992). Estimating the determinants of taxpayer compliance with experimental data. National Tax Journal, 107-114.

Alm, J., \& McKee, M. (1998). Extending the lessons of laboratory experiments on tax compliance to managerial and decision economics. Managerial and Decision Economics, 259-275.

Andreoni, J., Erard, B., \& Feinstein, J. (1998). Tax compliance. Journal of economic literature, 36(2), 818-860.

Asnawi, M., Baridwan, Z., Supriyadi, \& Ertambang. (2009). Analisis Keputusan Kepatuhan Pajak: Strategi Audit Random, Perceived Probability of Audit, dan Pemahaman Etika Pajak (Studi Eksperimen Laboratorium). Simposium Nasional 12 Palembang.

Becker, G. S. (1968). Crime and punishment: An economic approach. Journal of political economy, 76(2), 169-217.

Chau, G., \& Leung, P. (2009). A critical review of Fischer tax compliance model: A research synthesis. Journal of accounting and taxation, 1(2), 34.

Clotfelter, C. T. (1983). Tax evasion and tax rates: An analysis of individual returns. The review of economics and statistics, 363-373.

Dewi, G. A. K. R. S. (2014). Pengaruh Moralitas Individu dan Pengendalian Internal Pada Kecurangan Akuntansi (Studi Eksperimen pada Pemerintah Daerah Provinsi Bali). Universitas Udayana, Denpasar.

DJP. (2011). Laporan Tahunan 2011. Direktorat Jenderal Pajak.

DJP. (2012). Laporan Tahunan 2012. Direktorat Jenderal Pajak.

DJP. (2013). Laporan Tahunan 2013. Direktorat Jenderal Pajak.

DJP. (2014). Laporan Tahunan 2014. Direktorat Jenderal Pajak.

DJP. (2015). Laporan Tahunan 2015. Direktorat Jenderal Pajak.

Feld, L. P., \& Frey, B. S. (2007). Tax compliance as the result of a psychological tax contract: The role of incentives and responsive regulation. Law \& Policy, 29(1), 102-120.

Friedland, N., Maital, S., \& Rutenberg, A. (1978). A simulation study of income tax evasion. Journal of public economics, 10(1), 107-116. 
Ihtiyath Vol. 2 No. 1 September 2018

Hair, J. F., Black, W. C., Babin, B. J., \& Anderson, R. E. (2010). Multivariate Data Analysis. United State: Pearson Prentice Hall.

Kaplanoglou, G., \& Rapanos, V. T. (2015). Why do people evade taxes? New experimental evidence from Greece. Journal of Behavioral and Experimental Economics, 56, 21-32.

Kleven, H. J., Knudsen, M. B., Kreiner, C. T., Pedersen, S., \& Saez, E. (2011). Unwilling or unable to cheat? Evidence from a tax audit experiment in Denmark. Econometrica, 79(3), 651-692.

Nahartyo, E. (2012). Desain dan Implementasi Riset Eksperimen. Yogyakarta: UPP STIM YKPN.

Nahartyo, E., \& Utami, I. (2016). Panduan Praktis Riset Eksperimen. Jakarta: Indeks.

Palil, M. R. (2005). Does tax knowledge matters in self-assessment systems? evidence from Malaysian tax administrative. The Journal of American Academy of Business, Cambridge, 6(2), 80-84.

Puspitasari, E., Nurhayati, I., \& Meiranto, W. (2015). Teori Postur Motivasi Dalam Studi Eksperimen Keputusan Kepatuhan Pajak di Indonesia. Proceeding Fakultas Ekonomi.

Rahman, E. F. (2011). Pengaruh Probabilitas Pemeriksaan Pajak dan Konflik Wajib Pajak Terhadap Keputusan Pengelakan Pajak (Studi Eksperimen pada Mahasiswa Program Pasca Sarjana Fakultas Ekonomi Universitas Diponegoro Semarang). Universitas Dipenogoro, Semarang.

Reinganum, J. F., \& Wilde, L. L. (1985). Income tax compliance in a principal-agent framework. Journal of public economics, 26(1), 1-18.

Spicer, M. W., \& Thomas, J. E. (1982). Audit probabilities and the tax evasion decision: An experimental approach. journal of Economic Psychology.

Torgler, B. (2002). Speaking to theorists and searching for facts: Tax morale and tax compliance in experiments. Journal of Economic Surveys, 16(5), 657-683.

Yitzhaki, S. (1974). Income tax evasion: A theoretical analysis. Journal of public economics, 3(2), 201-202. 